\title{
煉瓨の気孔率についで
}

西原 利夫** 郡 利 矩*** 谷 哲 郎****

\section{On the porosity of bricks}

\section{by Toshio NishiHaRA, Toshinori KōRI and. Tetsurō TANI}

The porosity of a brick is calculated by comparison of apparent volume and its real volume of the brick. Therefore the porosity determined by this method shows the mean value of the sample, not that of each point.

As according to the result we obtained the stress distributions in compressed powder is very complex, it is thought that the porosity in a powdered material will be very different at each point.

As the porosity has relations between the resistance of spalling, crrosion and other properties of a brick, it will be difficult to exhibit the hole ability of the brick, if there is any point of high porosity, in spite of the mean low porosity.

Accordingly, it is desirable to know the distribution of porosity rather than to discuss about the mean value of the brick. The investigations to know the porosity by measurement of principal strain in a compressed powder, and the verification of this method, and the explanation on the distribution of the porosity on several cases are written on this report.

\section{1. 序 '言}

耐火煉瓦の気孔率は並型煉瓦または同程度の大きさ の塊を試料とし、1箇から普通 3 䇢以上の立方体を切 りだし，それら立方体の空吵の容積を真空室中におい て水で満たして測定し，それと試料の占める空間容積 とから気孔率を計算し，その算術平均をるつて，その 煉瓦の気孔率としている。したがつて得られた值は大 をな試料の平约值であつて，各部分部分のそれを示す ものではない，笵者らの研究によると，圧縮した粉体 内D応力分布はえわめて複雑であり，かつまた，その 応力は粉体の歪に関係あるととより，圧蹜した粉体内 の気孔率は各部において必すしも均一でないてとが考 えられる。

近来煉瓦の成形法が stiff mud を俅用するリプレス より乾式成形に移りつつあるため,その不均一性はに つそら甚だしくなりつつあると考えられる。気孔率は 煉瓦の耐スポーリング性，耐侵蝕，その他の諸性質に 大なる堅俰を有し，全体として気孔率が低々場合でも， 部分的に高点がある場合は当然充分なる能力を発揮

* 原稿受付 昭和28年11月24日

** 正員 京都大學機械工祭敎室

*** 正員 京都大學工學研究所

**** 正員 品川白䐈瓦株式會闬
しえないはずである。したがつて1箇の煉瓦の全体の 平均気孔率溜して論するよりは，その分布状態を知 るととが望ましい。

との報告は圧蹜せられた粉体内の任意の点の主奀を 測定するととによつてその気孔率を求める方法を研究 し，その方法が大した誤差なく使用できるととを検討 するとともに，二三の例について気孔率の分布状態を 明らかてしたものである。

\section{2. 粉体の気孔率と主歪との関係}

(1) 理論的考穿 未焼戗煉瓦和よび煉瓦素地の 気孔率につ、ては, その気孔中に存在する水分を無視 すると次のよう火考兊られる。

Fig. 1 は㨁径 $10 \mathrm{~cm}$ ，高さ $20 \mathrm{~cm}$ の鋼瑟筒金型中 そ圧力を加えるととなく，高さ $18 \mathrm{~cm}$ までマグネシア クリンカーの微粉末を均等に入れ，その中に白い粉で 球状の目印を入れて和々た場合の図である。乙れを 230 トンアムスラー耐圧試験㙨を使用して上方より圧 縮すると，その圧絽後の変形は Fig. 2 亿示すがととくく であつて, 圧縮前球状であつた目印はほぼ楕円形《変 形している．乙れは歪杵四体の $2 \supset の$ 主軸 $s_{1} ， \varepsilon_{2}$ を通 る平面で切つた断面であつて, 圧樎した粉体中の任意

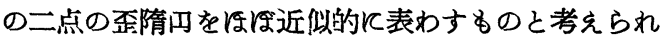




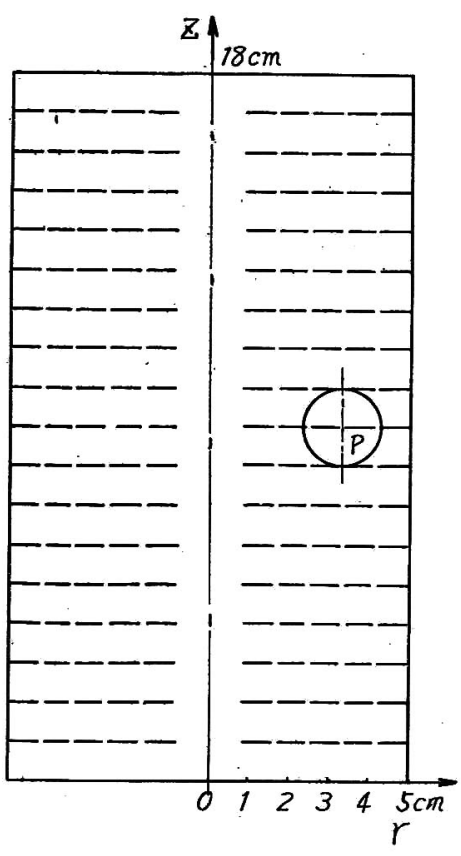

Fig. 1 Index of the powdered material filled in a cylindrical mould.

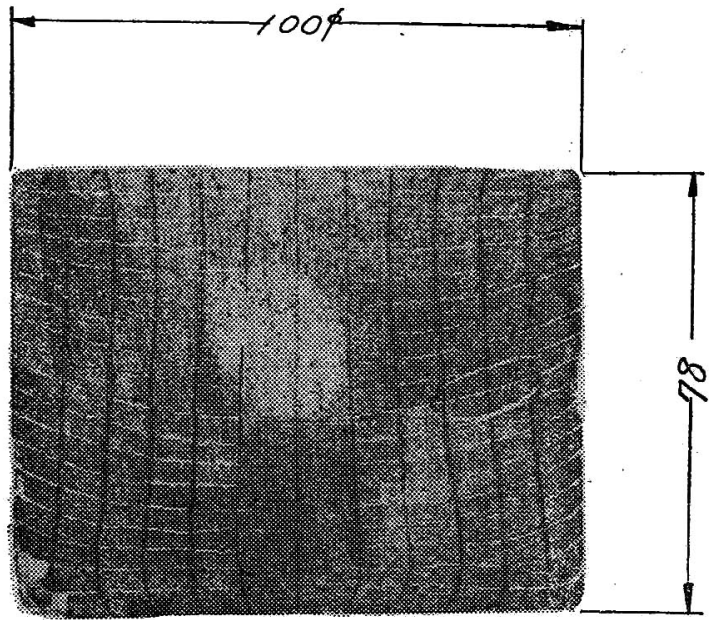

-Fig. 2 Deformed feature after compression from the top.

ち. 今 Fig. 3 (a) より压縮されFig. 3(b) Kなつた 場合を考元ると，P点を中心とする微小部分には压縮 の前後に的的て明ら加にその境界を通しての粉体の出 入はならから，压縮前半径 $\rho_{0}$ であつた球体は忹縮さ

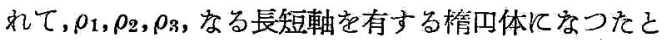
考允てもさしつか党ない. したがつて压縮前 $4 \pi \rho_{0}{ }^{3} / 3$ なる容蹟の部分は压樎されて $4 \pi \rho_{1} \rho_{2} \rho_{3} / 3$ の容積次 なつたととがわがる. 今との部分の見掛気孔率が零と ねつた場合の容積と同容積の球体を考えその半径を $\rho$

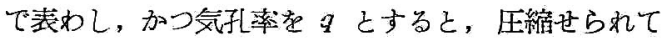
$\rho_{1}, \rho_{2}, \rho_{3}$ の長短軸存する楈内体となつを部分の気

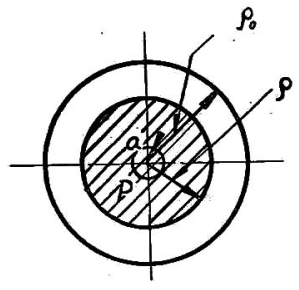

(a) Spherical index before comprossion

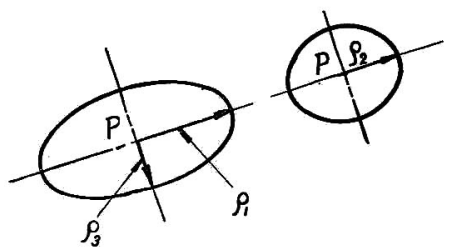

(b) Strain ellipsoid after compression

Fig. 3

孔率治前に報告せる通り気孔率の定義に従つて

$$
\begin{aligned}
q & =\left\{\left(\rho_{1} \rho_{2} \rho_{3}-\rho^{3}\right) / \rho_{1} \rho_{2} \rho_{3}\right\} \times 100 \\
& =\left\{1-\frac{\left(\rho_{1} / \rho_{0}\right)}{\left(\rho_{1} / \rho_{0}\right)\left(\rho_{2} / \rho_{0}\right)\left(\rho_{3} / \rho_{0}\right)}\right\} \times 100
\end{aligned}
$$

$\rho_{0}$ は粉体の圧縮前の状態により一定のものであり， まを $\rho$ は粉体の見掛此重より定まつてくるから， $\rho / \rho_{0}$ は一定の条件の原料に対しては一定であると考えてさ

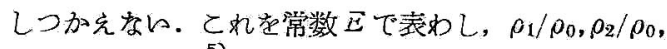
$\rho_{3} / \rho_{0}$ は前飞啹告しを表示法沉従うて $\varepsilon_{1}=\ln \left(\rho_{1} / \rho_{0}\right)$, $\varepsilon_{2}=\ln \left(\rho_{2} / \rho_{0}\right), \varepsilon_{3}=\ln \left(\rho_{3} / \rho_{0}\right)$ とすると, 上式壮次の よう炡る。

$$
q=\left(1-\frac{E^{3}}{e^{\varepsilon_{1}+\varepsilon_{2}+\varepsilon_{3}}}\right) \times 100
$$

乙たがつて圧縮した粉体内の任意の点の主再 $\varepsilon_{1}, \varepsilon_{2}$,

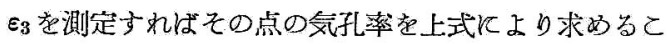
とがで悉る。

（2）実験的検討 今上飞述べを(2)式によつて 計算した気孔率の值が従来の浸水法に上つて得志描儿 比してとの程度の相違があるか在検討して見る. Fig. 4 注長軸 $10 \mathrm{~cm}$, 短軸 $5 \mathrm{~cm}$ の湓刀形の断面存す る金型の図の位置飞半径 $\rho_{0}=1 \mathrm{~cm}$ の球状の目印大 れを場合である。これを上方より压縮すると， 11 和よ

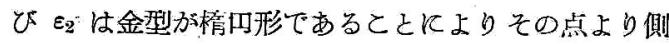
壁までの距離が方向によつて連続的に買なり，したが つてその点に及䄈与側壁と粉体との摩擦の影響が方向 によつて違つてくるため異なつた值をとる。また中心 線の上亩るため，压縮後も常に中心線上にあり，加

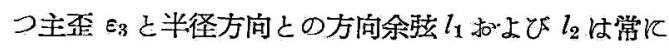
1 となり（2 式を検傠するのに便利である.

との金型々 Table 1 のどとき性質のマグネシアク リンカーの微粉末を $18 \mathrm{~cm} の$ 高さに入れて压縮した場

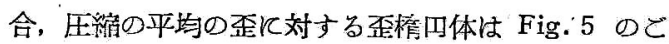




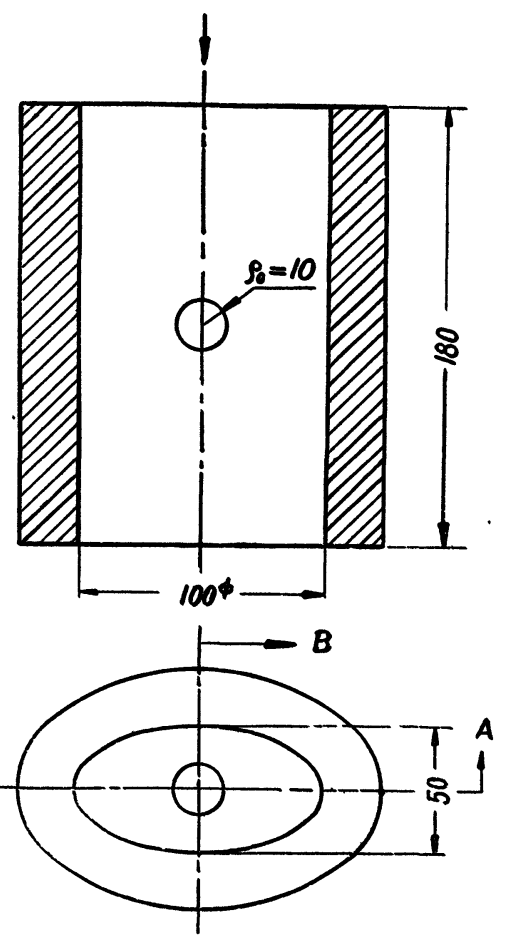

Fig. 4

とくである。との図より $\rho_{1} ， \rho_{2} ， \rho_{9}$ ，を測定し， $\varepsilon_{1}$, $\varepsilon_{2}, \varepsilon_{9}$ ，和上び気孔率 $q$ を計算すると, Table 2 のどと くになる，同表に和々て $\boldsymbol{q}$ (実験直)とあるのは Fig. 4 の球より Fig. 5 のどとくなつた歪隋四体を取り出して 従来つ浸水法によつて測定した值である。これら $2 つ$

Table 1 Characteristics of a specimen powder.

\begin{tabular}{c|c|c|c|c|c|c}
\hline Tyler mesh & $\begin{array}{c}60 \text { mesh } \\
\text { up }\end{array}$ & 100 & 150 & 200 & 250 & 250 low \\
\hline Percentage & $5 \cdot 4$ & $9 \cdot 4$ & $22 \cdot 0$ & $8 \cdot 0$ & $7 \cdot 7$ & 47.5 \\
\hline \hline$\because$ & $\begin{array}{l}\text { internal friction of specimen } \\
\text { powder }\end{array}$ & 0.393 \\
\hline$\lambda$ & $\begin{array}{l}\text { friction between powder and } \\
\text { cylinder wall }\end{array}$ & 0.220 \\
\hline Relation between stress and strain & $\sigma=1200 \mathrm{~s}^{13 \cdot 14}$ \\
\hline
\end{tabular}

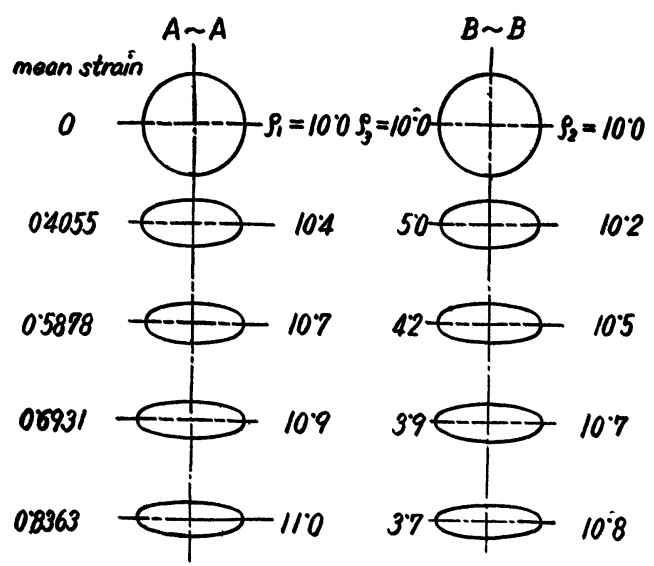

Fig. 5 Strain ellipsoids.

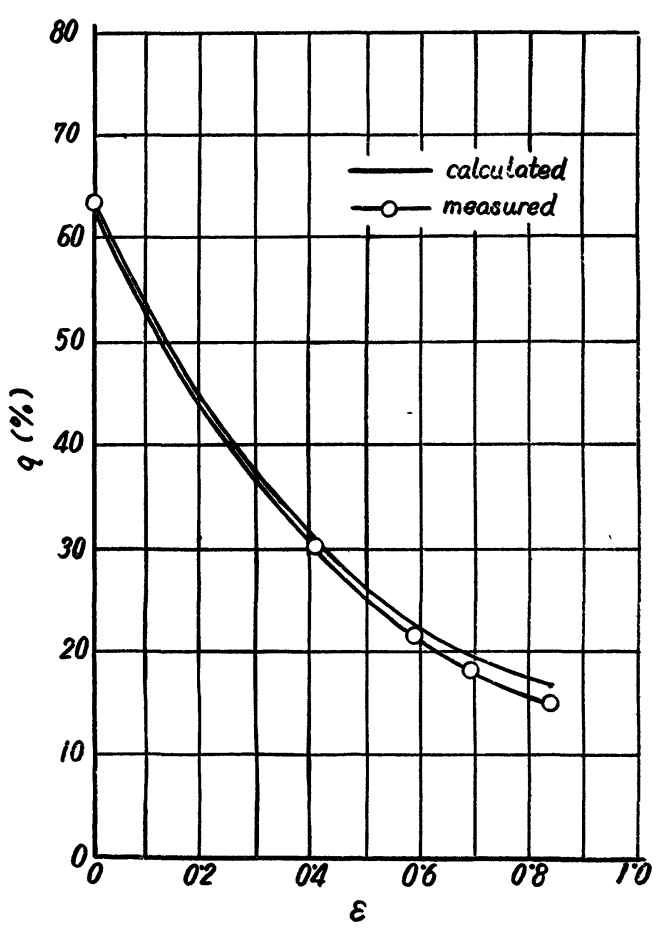

Fig. 6 Relation between $q$ and $\varepsilon=\varepsilon_{1}+\varepsilon_{2}+\varepsilon_{3}$.

Table 2 Values of $\varepsilon$ and $q$ calculated and mesured.

\begin{tabular}{c|c|c|c|c|c|c}
\hline $\begin{array}{c}\text { mean strain } \\
\varepsilon=\epsilon_{1}+\epsilon_{2}+\epsilon_{3}\end{array}$ & $\epsilon_{1}$ & $\epsilon_{2}$ & $\epsilon_{3}$ & $q$ (calculated) & \begin{tabular}{c}
$q$ (measured) \\
\hline 0
\end{tabular} & $\begin{array}{c}\text { difference of } \\
\text { both } \\
\text { porosity }\end{array}$ \\
\hline 0.4055 & -0.0392 & -0.0198 & +0.6931 & 30.8 & 30.5 & 0.3 \\
\hline 0.5878 & -0.0677 & -0.0488 & +0.8 .671 & 22.3 & 21.0 & 1.3 \\
\hline 0.6931 & -0.0862 & -0.0677 & +0.9416 & 19.3 & 18.1 & 1.2 \\
\hline 0.8363 & -0.0953 & -0.0770 & +0.9940 & 16.5 & 14.8 & 1.7 \\
\hline
\end{tabular}


の方法によつて得た気孔率とその歪 $\varepsilon=\varepsilon_{1}+\varepsilon_{2}+\varepsilon_{3}$ と の関係を図示すとFig.6のようとなる。その差は気 孔率が大きりれば少なく，気孔率が小さくなれば大と なるが，最大 $1.6 \%$ 以内であるから，かりに浸水法に よる測定值が正しいと考えても計算による值は充分実 用に耐えると考允られる。

以上は比較的大き球を入行考察したが，乙れい できるだけ小さい方が望ましく，かついつの試験体に つレて，各部の歪が測定でをなければならない。その 実際の方法につレては後に述べる方法を用放。

\section{3. 蛄成前の気孔率上蛄成後のそれとの関係}

一般に煉瓦素地扣よび不㷬成煤瓦を烧成せる場合， 粉体中の可燃物の燃筦於よび結晶構造の転位などによ り気孔率は焼成前とは異なつてくる。したがつて上述 の方法が㜔成煉瓦の場合飞も適肞できるかどらかを検 刢する必要がある。

（1）収樎のない場合焼成せる場合，全体的飞 收絽のないとき，その烧成前の気孔率との比較は Table 3 和よびFig. 7 K示すどとくであり，両者の気 孔率をそれそれ $q_{b} ， q_{w}$ とすると次心関保があるとと がわかる. 乙の場合実験は $\varepsilon_{1}=\varepsilon_{2}=0 K て \varepsilon_{9}$ のみを変 化させた。

$$
q_{b} / q_{u}=1+1 /\left(\left(54 \cdot 5 e^{-8}-18 \cdot 75\right)\right.
$$

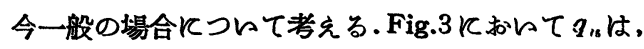

$$
q_{u}=\left\{\left(\rho_{1} \rho_{2} \rho_{3}-\rho^{3}\right) / \rho_{1} \rho_{2} \rho_{3}\right\} \times 100
$$

粉体中の可然物和上ひ附着水などは压縮前一様に分 散していると考光られるから，その可然物などに相当

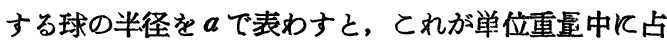
める容積は一定であり， $q_{b}$ は次のように表わされる。

$$
q_{b}=\left\{\frac{\rho_{1} \rho_{2} \rho_{3}-(\rho-a)^{3}}{\rho_{1} \rho_{2} \rho_{3}}\right\} \times 100
$$

したがつて

$$
\begin{aligned}
\frac{q_{b}}{q_{t}} & =\frac{\rho_{1} \rho_{2} \rho_{3}-(\rho-a)^{3}}{\rho_{1} \rho_{2} \rho_{3}} \\
& =1+\frac{3\left(\rho_{1} \rho_{0}\right)^{2}\left(a / \rho_{0}\right)-3\left(\rho / \rho_{0}\right)\left(a / \rho_{0}\right)^{2}}{\left(\rho_{1} / \rho_{0}\right)\left(\rho_{2} / \rho_{0}\right)\left(\rho_{3} / \rho_{0}\right)-\left(\rho / \rho_{0}\right)^{3}}
\end{aligned}
$$

Table 3 Values of $\varepsilon$ and $q_{b} / q_{16}$ being no shrinkage, calculated and measured.

\begin{tabular}{c|c|c}
\hline$\varepsilon$ & $q / q_{16}($ measured) & $q_{s} / q_{16}$ (calc.) \\
\hline 0 & 1.028 & 1.0280 \\
\hline 0.5111 & 1.077 & 1.0719 \\
\hline 0.5979 & 1.102 & 1.0895 \\
\hline 0.6931 & 1.139 & 1.1175 \\
\hline 0.7984 & 1.160 & 1.1735 \\
\hline
\end{tabular}

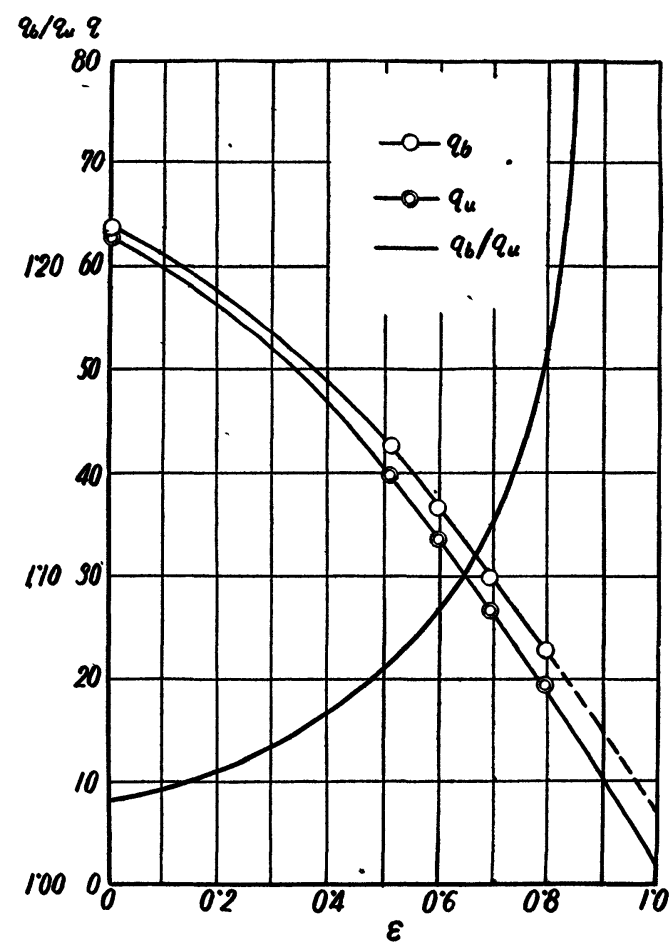

Fig. 7 Relation between $q$ and $\varepsilon=\varepsilon_{1}+\varepsilon_{2}+\varepsilon_{3}$, $q_{b} / q_{u}$ and $\varepsilon$.

$\rho_{0}$ は粉体の圧縮前の状態により定まるすのであり， また単位重量中に占める可燃物の容積は一定であるか

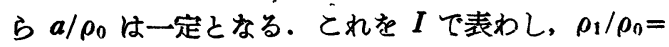
$e^{\varepsilon_{1}}, \rho_{2} / \rho_{0}=e^{\varepsilon_{2}}, \rho_{3} / \rho_{0}=e^{\varepsilon_{3}}, \rho / \rho_{0}=E$ を代入すると，

$$
\frac{q_{b}}{q_{u}}=1+\frac{3 E^{2} I-3 E I^{2}+I^{3}}{e^{\varepsilon_{1}+\varepsilon_{2}+\varepsilon_{3}}-E^{3}}
$$

ての式和にて $E$ 和よびIはとれそれ定数である から，上式は次の形で表わされる。

$$
\frac{q_{b}}{q_{u}}=1+\frac{1}{A e^{\varepsilon}-B}
$$

ただし $A, B$ 壮，

$$
\begin{aligned}
& A=\frac{1}{3 E^{2} I-3 E I^{2}+I^{3}} \\
& B=\frac{E^{3}}{3 E^{3} I-3 E I^{2}+I^{3}}
\end{aligned}
$$

使用しを粉体の $E^{3}=0.331 ， I=0.013$ であるから， とれを(5)，(6) 亿代入して $A, B$ を求的ると, $A=54 \cdot 60, B=18.04$ となり, (3)式とほほ同一の式 を得られる. このととより(3)式は理論的にも正しい と考充られ，乙の式を求めて扎くととより，同一の 粉体を使用する場合は焼成前の気孔率より焼成後の気 孔率の分布を求めるととができる。

（2）収縮のある場合収縮のある場合の焼成前 の気孔率との比較は Table 4 於よび Fig. 8 K示すがど とくであり，両者の気孔率は次のどとき関係にある。 
Table 4 Values of $\varepsilon$ and $q_{b} / q_{16}$ of burned brick being calculated and measured.

\begin{tabular}{c|c|c}
\hline$\varepsilon$ & $q b / q_{u}($ measured) & $q b / q_{u}$ (calc.) \\
\hline 0 & 0.616 & 0.6065 \\
\hline 0.5111 & 0.638 & 0.6523 \\
\hline 0.5979 & 0.665 & 0.6736 \\
\hline 0.6931 & 0.706 & 0.7109 \\
\hline 0.7984 & 0.742 & 0.7437
\end{tabular}

$q_{s} / q_{u} q$

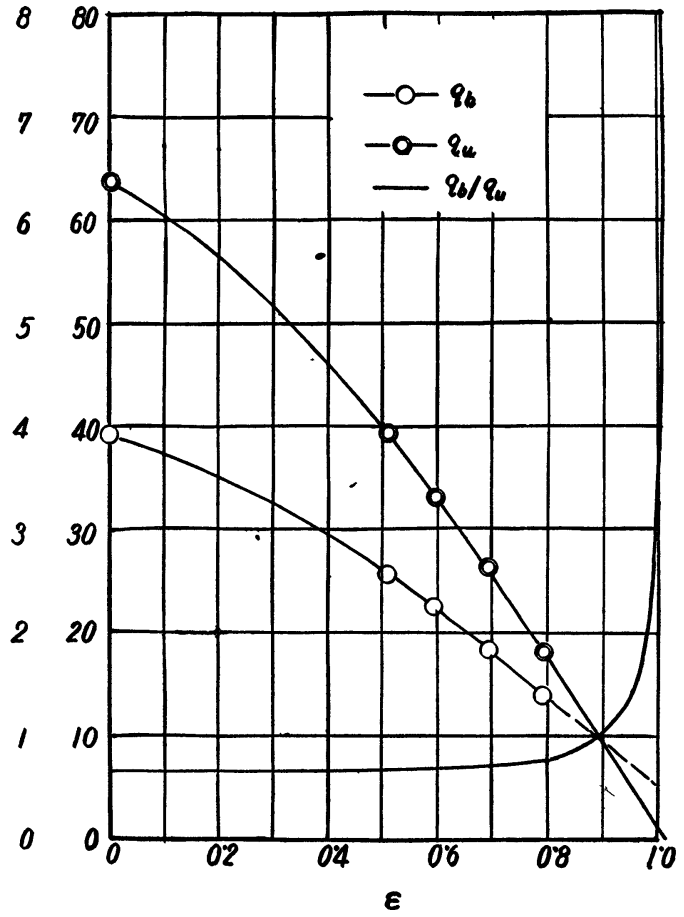

Fig. 8 Relation between $q$ and $\varepsilon=\varepsilon_{1}+\varepsilon_{3}+\varepsilon_{2}$, $q_{b} / q_{1}$ and $\varepsilon$.

$$
\left(q_{b} / q_{1 b}-0.55\right)(\varepsilon-1.01)=-0.051
$$

乙の場合も同様《㜔成前の気孔率より, 焼成後の気 孔率を求めるととがでをる，乙の理論的取扱いは後日 くゆする。

\section{4. 測 定 結 果}

Fig. 9 は Fig. 2 の筒形金型に粉体を入れて, 片侧 より圧縮した場合の歪線図を使用して，前に発表した 論交中で詳細に述べた方法により各点の主歪を測定 し，(2)式により気孔率の分布を調べを結果である. これは未焼成の場合であるが，その気孔率は中心に和

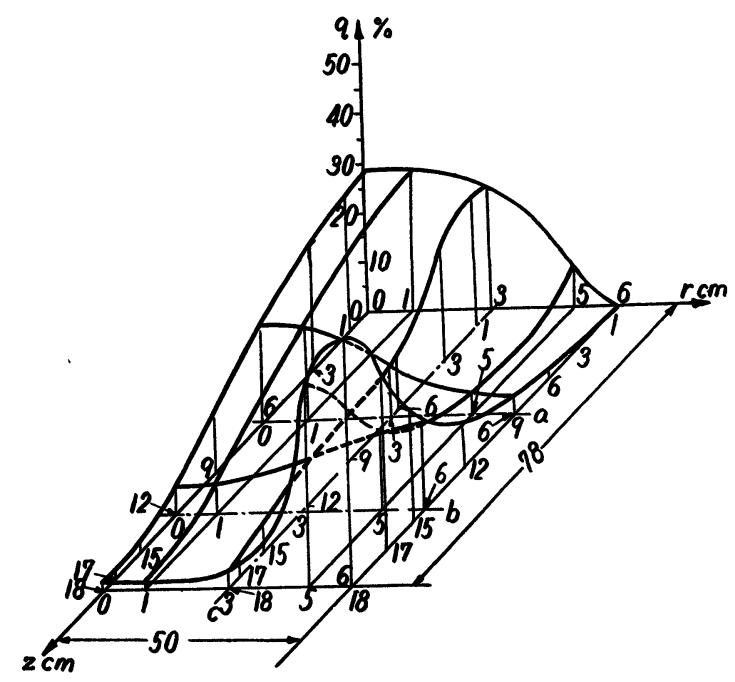

Fig. 9 Porcsity distribution of a compresjed powder in a cylinder.

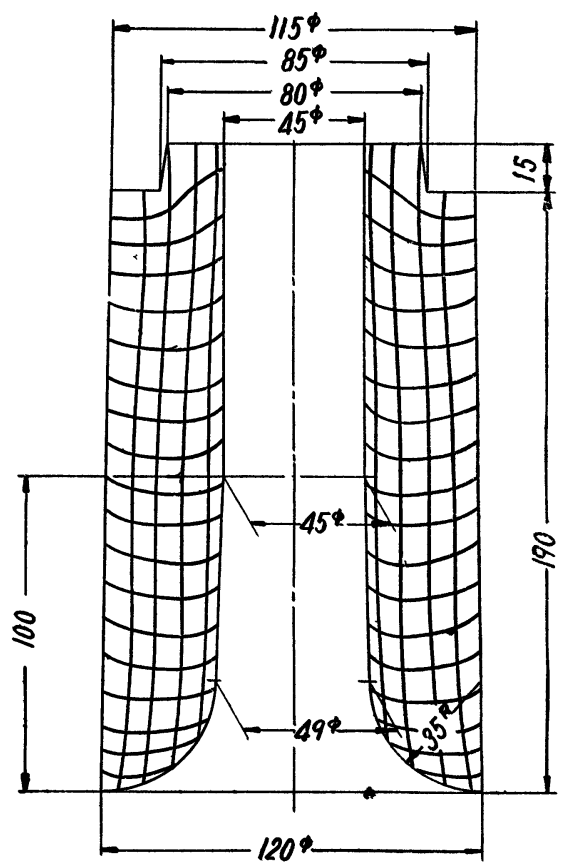

Fig. 10 Deformation feature of a nozzle.

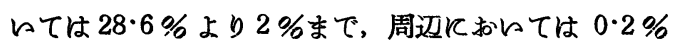
より 49.8\%まで大きく変化している.Fig.10はノズ ルの金型に同一の試料を入れ，上下より圧縮した場合 の歪線図であり，この歪線図より各点の主歪を測定し て，(2)式により気孔率の分布を調べた結果がFig.11 である。この場合も気孔率は各部に利にてはなはだし。 く不同であるととがわかる. 


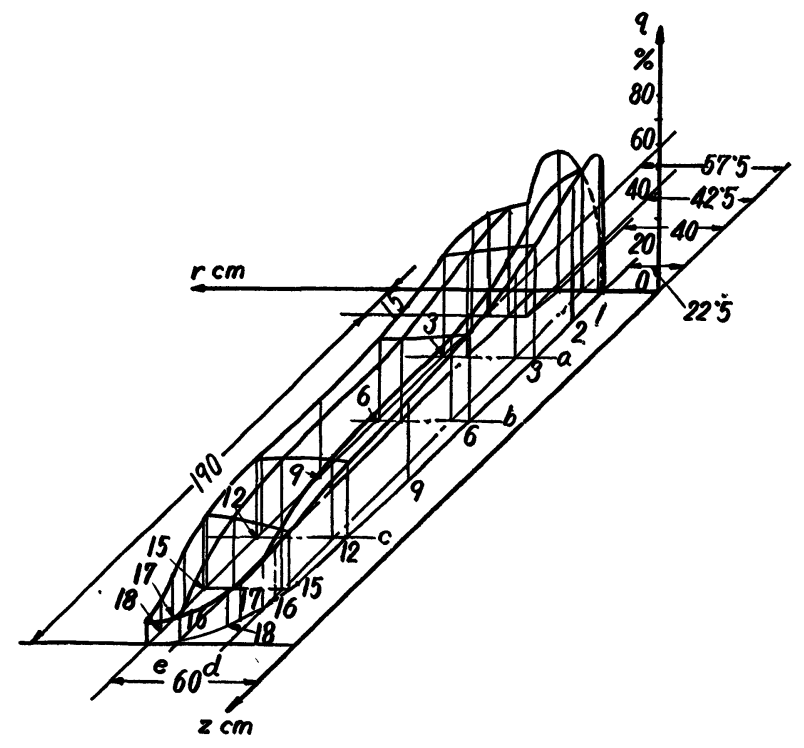

Fig. 11 Porosity distribution of a compressed powder in a nozzle shape mould.

\section{5. 測定結果の検討}

上、得た気孔率の分布が正しいかどらかを検討して 見る.今円筒形金型中において圧縮した粉体内の任意 の点の気孔率を不焼成の場合 $q_{16}(r, \theta, z)$ で表わすと, Fig. 12 に扣衫

$$
q_{u}(r, \theta, z)=\frac{d V u}{d V}
$$

そだし、、V は微小部分の中に存在する気孔の容積， dVは微小部分全体の容積とする。したがつて

$$
d V_{u}=q_{u}(r, \theta, z) d V
$$

一方 Fig. 12 より

\section{$d V=r d r d \theta d z$}

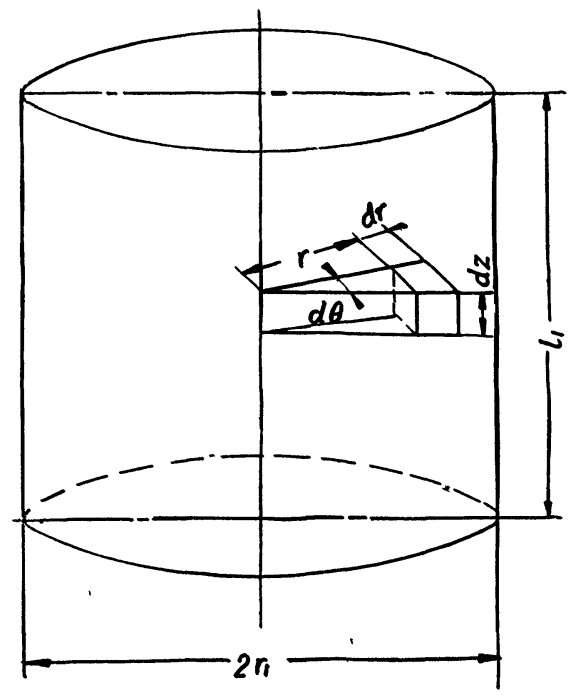

Fig. 12
W九र $d V_{u}=q_{u}(r, \theta, z) r d r d \theta d z$

これを試料全体につレて積分すると試料全体中に存 在する気孔の容積は

$$
\begin{aligned}
V_{u} & =\int_{0}^{2} \int_{0}^{l_{1}} \int_{0}^{r_{1}} q_{u}(r, \theta, z) r d r d \theta d z \\
& =2 \pi \int_{0}^{l_{1}} \int_{0}^{r_{1}} q_{16}(r, z) r d r d z
\end{aligned}
$$

一万この試料全体の容積 $V$ は

$$
V=\pi r_{1}^{2} l_{1}
$$

したがつて試料全体の平均気孔率 $q_{m}$ は

$$
q_{m}=\frac{V v_{n}}{V} \times 100=\frac{2 \pi \int_{0}^{z_{1}} \int_{0}^{r_{1}} q_{n}(r, z) r d r d z}{\pi r_{1}^{2} l_{1}} \times 100(8)
$$

これは気孔率の分布を知れば近似值を求めるととが できる。

Fig. 11 の気孔率の分布より計算した $q_{m}$ は，22・1\%

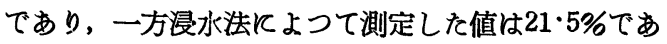
つた・じがつて，その誤差は僅少であり，計算した 気孔率の分布は正しいものと考えて差しつかえない。

\section{9. 結曾}

（1）压縮せられた粉体内の気孔率と主歪との間の 関係について考察を行い,その関係式を理論的に導び レた。

（2）そして焼成前の気孔率と焼成後の気孔率との 間に一定の関係があるととを実験牨に確かめ, 収縮の ない場合, 収縮のある場合につレて $q_{b} / q_{u b}$ とと間 の関係式を求めた。

(3) さらに上に導び々た気孔率と主票の関保式を 用いて，2つの例について压縮せられた粉体内の気孔 率の分布状態を調べ, 気孔率は同一試料においてもそ の場所によつてはなはだしく異なつているとと示し， 従来の浸水法による測定は単に平均値を与えるのみで あつて，そのものの真の性質を代表する気孔率を与え るものではないととを示した。

（4）上に得た気孔率の分布より，その試料全体の 平均気孔率 $q_{m}$ を計算によつて近似的に求め, 浸水法 による $q_{m}$ とよく一致するととを確かめた。

以上飞得た結果は気孔率の分布につにてであるが, 気孔率は収縮膨脹, 抗張力, 通気率などに関係あり, したがつて焼成時の応力, 耐侵蝕性, 乾燥などにつ々 ても調らべられるはずである.さらに実験を行々，乙 こらの気孔率分布の影勯を明らかにしたん。

注: 一

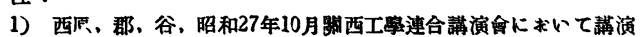

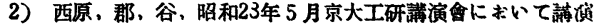

3）西原，郡、谷、昭和28年 9 月第 3 回磼力學會連合㴋演會に救い 乙恋演

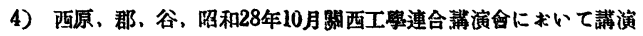

5) 郡、谷、材料試驗㙝會誌、 2 急, 9 呺 